\title{
EFFECT OF EXPERIMENTAL INFARCTION, MANUAL MASSAGE, AND ELECTRICAL DEFIBRILLATION ON MYOCARDIAL LIPOPROTEIN LIPASE ACTIVITY OF DOGS *
}

\author{
By JACQUES I. KESSLER $\dagger$ AND ELLIOT SENDEROFF $\ddagger$
}

(From the Departments of Medicine and Experimental Surgery, and the Nutrition Laboratory, The Mount Sinai Hospital, New York, N. Y.)

(Submitted for publication December 21, 1961 ; accepted March 8, 1962)

It has been demonstrated that heart muscle contains lipoprotein lipase (LPL) in high concentrations $(1,2)$. This enzyme, which appears to be identical with the post-heparin "clearing factor," specifically hydrolyzes the triglyceride component of chylomicrons and other low density lipoproteins (3).

It is assumed that the enzyme is held on the cell surfaces by electrostatic forces (4) and is in equilibrium with small quantities of circulating LPL (5). Injection of heparin (6) and other substances with negatively charged polar groups (7-10) is followed by a prompt appearance of LPL activity in the circulation. These observations suggest that alteration of the electrostatic forces holding the enzyme to the binding sites on the cell surfaces may account for the immediate action of these substances.

Ligation of the coronary artery produces immediate electrocardiographic (ECG) changes, which are assumed to reflect the disturbed equilibrium of the electrostatic forces over the infarcted area. Manual massage, by producing subepicardial damage, can also result in changes of the surface electrostatic forces. Infarction and massage affect the electrostatic forces of the damaged surfaces only. Electrical defibrillation, on the other hand, can disturb the electrostatic equilibrium of the entire myocardium.

This study was undertaken in order to demonstrate the effect of myocardial infarction, manual massage, and electrical defibrillation on the level of myocardial LPL. It was assumed that these factors would release the enzyme from its binding sites by a possible effect on the electrostatic forces

\footnotetext{
* Supported in part by grants from the Division of Research Grants and Fellowships, National Institutes of Health.

+ Research Fellow in Medicine.

$\$$ Research Fellow, New York Heart Association.
}

similar to that exerted by certain electronegatively charged macromolecular substances.

\section{METHODS}

The experiments were performed on 28 mongrel dogs weighing 10 to $12 \mathrm{~kg}$. Each dog was anesthetized with sodium pentobarbital (Nembutal; 25 to $30 \mathrm{mg}$ per $\mathrm{kg}$ body weight, i.v.), and connected to a positive pressure breathing apparatus and a direct-vision electrocardiograph.

Ligation of the left circumflex coronary artery at its origin was performed through a left-sided thoracotomy in the fifth intercostal space. ECG tracings were taken before and at varied intervals after ligation.

Manual massage was applied by rhythmical pressure over the ventricles only.

Electrical defibrillation was effected by a cardiac defibrillator that sends a pulse of 1.5 to 3.5 amps through the heart, with a duration of 0.15 second and an amplitide of $150 \mathrm{v}$.

The dogs either expired shortly after placement of the ligature or were sacrificed by exsanguination; the heart was taken for LPL studies. The excised heart was washed with ice-cold saline and examined immediately, or it was frozen and the studies were performed several days later. Preliminary studies showed that freezing the heart for several days did not affect the myocardial LPL activity.

Release of LPL activity from heart muscle was examined by incubating myocardial slices taken from the atria, ventricles, and area of infarction in the presence of heparin. Each slice, weighing approximately $1 \mathrm{~g}$, was sectioned with a razor blade into multiple thin slices, each weighing $50 \mathrm{mg}$ or less. They were placed in $25-\mathrm{ml}$ Erlenmeyer flasks, each containing $1 \mathrm{ml}$ of KrebsRinger phosphate buffer ( $\mathrm{pH} 7.4$ ) per $100 \mathrm{mg}$ wet weight of tissue, and incubated at $37^{\circ} \mathrm{C}$ with gentle agitation. Sodium heparin ${ }^{1}$ in a final concentration of $30 \mu \mathrm{g}$ per $\mathrm{ml}$ was added to the incubation medium. After 1 hour of incubation the lipase activity of two aliquots of each incubation medium was assayed for its ability to produce free fatty acids (FFA) from a standard cottonseed oil (Lipomul 2) substrate. The triglyceride substrate was

${ }^{1}$ Liquaemin, $10 \mathrm{mg}$ per $\mathrm{ml}, 1,000$ USP U per $\mathrm{ml}$; Organon Inc., West Orange, N. J.

${ }^{2}$ Lipomul, Upjohn Co., Kalamazoo, Mich. Contains in per cent : 15 cottonseed oil, 4 dextrose, 1.2 lecithin, and 0.35 oxyethylene oxypropylene polymer. 
TABLE I

Analysis of 22 dogs subjected to coronary arterial ligation

\begin{tabular}{|c|c|c|c|c|c|}
\hline \multicolumn{3}{|c|}{ Died } & \multicolumn{3}{|c|}{ Survived } \\
\hline $\begin{array}{c}\text { Ventric. } \\
\text { fibril. } \\
\text { Dog no. }\end{array}$ & $\begin{array}{l}\text { Ventric. } \\
\text { fibril. } \\
\text { +massage } \\
\text { Dog no. }\end{array}$ & $\begin{array}{c}\text { Ventric. } \\
\text { fibril., } \\
\text { massage, } \\
\text { and/or } \\
\text { defib. } \\
\text { Dog no. }\end{array}$ & $\begin{array}{l}\text { Survived } \\
\text { after mas- } \\
\text { sage and } \\
\text { defib. } \\
\text { Dog no. }\end{array}$ & $\begin{array}{l}\text { Survived } \\
\text { for } 24-48 \mathrm{hrs} \\
\text { Dog no. }\end{array}$ & $\begin{array}{c}\text { Survived; } \\
\text { sacrificed } \\
\text { after } 2 \mathrm{mo} \\
\text { Dog no. }\end{array}$ \\
\hline $\begin{array}{l}1 \\
2 \\
3 \\
4\end{array}$ & $\begin{array}{l}5^{*} \\
6 \\
7\end{array}$ & $\begin{array}{r}8 \\
9 \\
10 \\
11 \\
12\end{array}$ & $\begin{array}{l}13 \\
14\end{array}$ & $\begin{array}{l}15 \\
16 \\
17 \\
18 \\
19 \\
20\end{array}$ & $\begin{array}{l}21 \\
22\end{array}$ \\
\hline
\end{tabular}

* Survived the infarction, sacrificed after 5 minutes of ventricular massage without preceding ventricular fibrillation.

activated by incubation at $37^{\circ} \mathrm{C}$ for 30 minutes and consisted of 8 parts 10 per cent bovine serum albumin ${ }^{3}$ in phosphate buffer $(0.16 \mathrm{M})$, titrated with ammonium hydroxide to $\mathrm{pH} 8.7$; one part of 5 per cent cottonseed oil (prepared by dilution of Lipomul in the phosphate buffer); and one part of fresh human serum. Equal amounts (1 $\mathrm{ml}$ ) of each incubation medium and the "activated" triglyceride substrate were mixed and incubated with frequent shaking for 1 hour. The difference in the FFA content of the nonincubated and the incubated mediumsubstrate mixture in microequivalents released by $1 \mathrm{~g}$ wet weight of myocardium during 1 hour of incubation was taken to express the lipolytic activity. The lipolytic reaction of the mixtures was terminated by addition of the isopropanol-heptane extraction mixture used in the determination of FFA.

Free fatty acids were determined according to the method of Dole (11) as modified by Trout, Estes and Friedberg (12) except that Nile blue $A$ was used as a titration indicator (13).

The myocardial LPL content was determined by the method described by Korn (1). The acetone-dried, ammonia-extracted $(50 \mathrm{mg}$ per $\mathrm{ml}$ ) and lyophilized powder obtained from the atrial, ventricular; and infarcted myocardium was dissolved in saline, and aliquots were taken for assay of lipolytic activity as described. The activity was expressed in microequivalents of FFA per gram of protein of the saline-dissolved powder liberated during 1 hour of incubation.

Protein was determined by the method of Lowry, Rosebrough, Farr and Randall (14).

\section{RESULTS}

Effect of experimental myocardial infarction on the cardiac activity of dogs. The effect of infarction on the cardiac activity is summarized in Table I. Thirteen of the 22 dogs examined developed ventricular fibrillation almost immediately after ligation of the coronary artery; 11 of them

\footnotetext{
${ }^{3}$ Bovine serum albumin, fraction V, Armour Pharmaceutical Co., Kankakee, I11.
}

expired shortly after placement of the ligature despite attempts at defibrillation by manual massage, or electrical defibrillation, or both. Dog 5 survived the infarction, but its ventricles were massaged for 5 minutes without preceding ventricular fibrillation, and it was sacrificed. These 12 dogs were divided into three groups: those examined for the effect of infarction and ventricular fibrillation (dogs 1-4), those whose hearts were massaged (dogs $5-7$ ), and those receiving electrical defibrillation alone or in addition to ventricular massage (dogs 8-12).

Ten dogs survived the infarction without complications. They were also divided into three groups: those surviving for 24 to 48 hours (dogs 15-20), those that survived but were sacrificed 2 months after the operation (dogs 21, 22), and those that had developed ventricular fibrillation but whose cardiac activity was returned to normal by massage and electrical defibrillation (dogs 13, 14).

Placement of the coronary ligature resulted in immediate appearance of a well delimited area of infarction over the left ventricle, concomitantly with occurrence of typical changes in ECG. It was not possible to record the changes in ECG caused by infarction in the dogs with ventricular fibrillation, but they all developed a visually well demarcated area of infarction.

Effect of heparin on release of myocardial lipolytic activity in vitro. Incubation of myocardial slices obtained from the atria or ventricles of five normal dogs in the presence of heparin resulted in a marked elevation of the lipolytic activity of the incubation medium (Table II). Incubation in the absence of heparin was followed by release of a 
minimal activity. The heparin-released lipolytic activity from the atrial and ventricular myocardium was in a very close range.

Demonstration of the identity of the heparin-released myocardial lipolytic activity with LPL. To demonstrate the identity of the heparin-released lipolytic activity with LPL, the effect of some factors known to influence the activity of LPL (1) were examined. Protamine sulfate and $1 \mathrm{M}$ $\mathrm{NaCl}$, which inhibit LPL, also inhibited the myocardial lipolytic activity released in the presence of heparin. As with LPL, maximal activity was determined at $\mathrm{pH}$ 8.5. Incubation at $\mathrm{pH} 9$ or 7.4 produced a marked inhibition of the lipolytic reaction.

It has been demonstrated by Nikkilä (15) that post-heparin LPL can be adsorbed on calcium phosphate gel from which a partially purified enzyme can be obtained by elution with sodium citrate. The heparin-released myocardial lipase was also adsorbed by $\mathrm{Ca}_{3}\left(\mathrm{PO}_{4}\right)_{2}$ gel, and a good recovery of the enzyme was demonstrated in the eluate.

LPL activity of acetone-dried myocardial powder of normal dogs. The acetone-dried powder obtained from the atrial and ventricular myocardium of six normal dogs exhibited high LPL activity (Table II). There was no significant difference between the LPL content of the atrial and ventricular myocardium.

Effect of experimental infarction on myocardial $L P L$ activity. Infarction of the myocardium produced a marked decrease of the LPL activity of
TABLE II

LPL content of myocardial acetone-dried powder and heparinreleased LPL activity of normal dogs

\begin{tabular}{|c|c|c|c|}
\hline & \multicolumn{2}{|c|}{$\begin{array}{c}\text { LPL activity of } \\
\text { incubation medium }\end{array}$} & \multirow{2}{*}{$\begin{array}{l}\text { LPL activity } \\
\text { of acetone- } \\
\text { dried powde }\end{array}$} \\
\hline & $\begin{array}{c}\text { With } \\
\text { heparin }\end{array}$ & $\begin{array}{l}\text { Without } \\
\text { heparin }\end{array}$ & \\
\hline & \multicolumn{2}{|c|}{$\underset{t i s s u e / h r}{F F A}$} & $\begin{array}{c}F F A, \mu E q / \\
g \text { protein/hr }\end{array}$ \\
\hline Atria & $\begin{array}{l}15.6 \\
14.9 \\
15.3 \\
16.5 \\
18.8\end{array}$ & $\begin{array}{l}1.9 \\
1.7 \\
2.8 \\
1.9 \\
2.2\end{array}$ & $\begin{array}{l}593.5 \\
913.0 \\
543.5 \\
615.0 \\
710.0 \\
862.7\end{array}$ \\
\hline Ventricles & $\begin{array}{l}14.9 \\
15.2 \\
15.7 \\
17.2 \\
17.9\end{array}$ & $\begin{array}{l}2.6 \\
1.8 \\
2.4 \\
2.2 \\
1.8\end{array}$ & $\begin{array}{l}640.0 \\
896.5 \\
525.5 \\
692.0 \\
821.5 \\
812.8\end{array}$ \\
\hline
\end{tabular}

the involved area (Table III). The infarcted muscle was depleted of LPL, as is shown by the parallel decrease in the activity of the acetonedried powder and the activity released by heparin. The time of survival was without effect on the level of LPL in the infarcted myocardium. The degree of LPL depletion after 48 hours of survival (dogs 16, 20) was similar to that after 3 minutes ( $\operatorname{dog} 1)$. The low level of LPL in the infarcted area of the dogs sacrificed 2 months after the infarction (dogs 21,22 ) reflects the degree of replacement of heart muscle with fibrotic tissue, rather than an inability for LPL regeneration.

Effect of ventricular fibrillation and infarction on myocardial LPL activity. When the coronary

TABLE III

Effect of experimental infarction and ventricular fibrillation on myocardial LPL activity

\begin{tabular}{|c|c|c|c|c|c|c|c|c|}
\hline & \multirow[b]{3}{*}{$\begin{array}{l}\text { Dog } \\
\text { no. }\end{array}$} & \multirow[b]{3}{*}{$\begin{array}{c}\text { Survival } \\
\text { time }\end{array}$} & \multicolumn{6}{|c|}{ LPL activity } \\
\hline & & & \multicolumn{3}{|c|}{ Heparin-released } & \multicolumn{3}{|c|}{ Acetone-dried powder } \\
\hline & & & $\begin{array}{c}\text { Normal } \\
\text { atria }\end{array}$ & $\begin{array}{c}\text { Normal } \\
\text { vent. }\end{array}$ & $\begin{array}{c}\text { Infarc. } \\
\text { area }\end{array}$ & $\begin{array}{l}\text { Normal } \\
\text { atria }\end{array}$ & $\begin{array}{c}\text { Normal } \\
\text { vent. }\end{array}$ & $\begin{array}{c}\text { Infarc. } \\
\text { area }\end{array}$ \\
\hline & & & \multicolumn{3}{|c|}{$F F A, \mu E q / g$ wet wt tissue $/ h r$} & \multicolumn{3}{|c|}{$F F A, \mu E q / g$ protein $/ h r$} \\
\hline $\begin{array}{l}\text { Experimental } \\
\text { infarction }\end{array}$ & $\begin{array}{l}15 \\
16 \\
17 \\
18 \\
19 \\
20 \\
21 \\
22\end{array}$ & $\begin{array}{c}36 \mathrm{hr} \\
48 \mathrm{hr} \\
24 \mathrm{hr} \\
36 \mathrm{hr} \\
24 \mathrm{hr} \\
48 \mathrm{hr} \\
2 \mathrm{mo} \\
2 \mathrm{mo}\end{array}$ & $\begin{array}{l}16.6 \\
13.7\end{array}$ & $\begin{array}{l}14.2 \\
15.7 \\
13.9 \\
16.1 \\
14.9 \\
15.6 \\
16.8\end{array}$ & $\begin{array}{l}2.4 \\
2.1 \\
1.9 \\
2.5 \\
3.3 \\
4.1 \\
3.7 \\
3.8\end{array}$ & $\begin{array}{l}543.0 \\
676.5\end{array}$ & 728.5 & $\begin{array}{l}51.2 \\
\\
61.5 \\
82.4 \\
\\
53.2 \\
94.2\end{array}$ \\
\hline $\begin{array}{l}\text { Infarction }+ \\
\text { ventricular } \\
\text { fibrillation }\end{array}$ & $\begin{array}{l}1 \\
2 \\
3 \\
4\end{array}$ & $\begin{array}{l}3 \mathrm{~min} \\
10 \mathrm{~min} \\
12 \mathrm{~min} \\
20 \mathrm{~min}\end{array}$ & $\begin{array}{l}16.4 \\
15.7 \\
13.6 \\
15.4\end{array}$ & $\begin{array}{l}15.8 \\
14.9 \\
14.5 \\
18.3\end{array}$ & $\begin{array}{l}4.2 \\
3.4 \\
2.9 \\
3.3\end{array}$ & 593.4 & $\begin{array}{l}586.5 \\
710.0 \\
643.0\end{array}$ & $\begin{array}{l}83.2 \\
64.2 \\
82.4 \\
91.8\end{array}$ \\
\hline
\end{tabular}


TABLE IV

Effect of ventricular massage and of electrical defibrillation on myocardial LPL activity

\begin{tabular}{|c|c|c|c|c|c|c|c|c|}
\hline & \multirow[b]{3}{*}{$\begin{array}{l}\text { Dog } \\
\text { no. }\end{array}$} & \multirow[b]{3}{*}{$\begin{array}{l}\text { Duration, } \\
\text { massage }\end{array}$} & \multicolumn{6}{|c|}{ LPL activity } \\
\hline & & & \multicolumn{3}{|c|}{ Heparin-released } & \multicolumn{3}{|c|}{ Acetone-dried powder } \\
\hline & & & Atria & $\begin{array}{l}\text { Right } \\
\text { vent. }\end{array}$ & $\begin{array}{c}\text { Infarc. } \\
\text { area }\end{array}$ & Atria & $\begin{array}{l}\text { Right } \\
\text { vent. }\end{array}$ & $\begin{array}{c}\text { Infarc. } \\
\text { area }\end{array}$ \\
\hline & & $\min$ & \multicolumn{3}{|c|}{$F F A, \mu E q / g$ wet wt tissue $h r$} & \multicolumn{3}{|c|}{$F F A, \mu E q / g$ protein $/ h r$} \\
\hline $\begin{array}{l}\text { Ventricular } \\
\text { massage }\end{array}$ & $\begin{array}{l}5^{*} \\
6 \\
7\end{array}$ & $\begin{array}{r}3 \\
12 \\
18\end{array}$ & $\begin{array}{l}16.5 \\
15.6 \\
19.7\end{array}$ & $\begin{array}{l}4.8 \\
2.4 \\
3.6\end{array}$ & $\begin{array}{l}1.9 \\
1.5 \\
0.9\end{array}$ & $\begin{array}{l}586.5 \\
624.0\end{array}$ & $\begin{array}{l}61.0 \\
72.5\end{array}$ & $\begin{array}{l}82.1 \\
91.8\end{array}$ \\
\hline $\begin{array}{l}\text { Massage and/or } \\
\text { electrical } \\
\text { defibrillation }\end{array}$ & $\begin{array}{r}8 \\
9 \\
10 \\
11 \\
12\end{array}$ & & $\begin{array}{l}4.3 \\
3.8 \\
5.4 \\
4.2 \\
3.0\end{array}$ & $\begin{array}{l}5.4 \\
4.4 \\
2.4 \\
3.8 \\
2.0\end{array}$ & $\begin{array}{l}1.0 \\
1.3 \\
1.4 \\
2.2 \\
1.3\end{array}$ & $\begin{array}{l}62.1 \\
51.8 \\
74.2 \\
80.9 \\
71.9\end{array}$ & $\begin{array}{l}61.9 \\
41.6 \\
84.2 \\
81.2 \\
81.0\end{array}$ & $\begin{array}{l}72.4 \\
50.9 \\
63.6 \\
91.0 \\
71.4\end{array}$ \\
\hline
\end{tabular}

* Massage applied without preceding fibrillation.

ligation produced ventricular fibrillation in addition to infarction, the infarcted muscle was depleted of LPL to a degree similar to that of infarction alone (Table III). Ventricular fibrillation lasting 3 to 20 minutes was without effect on the LPL activity of the uninfarcted atrial and right ventricular muscles. Hypoxia, lasting even for 20 minutes, which can be induced by the reduced cardiac output of the fibrillating ventricles, was without effect on the LPL activity of the "undamaged" parts of the myocardium. Of particular interest, however, is the significant and prompt LPL depletion of the infarcted muscle, which occurred as fast as 3 minutes after placing the ligature. This depletion cannot be related to myocardial necrosis, since no significant necrotic changes can take place during this short interval.

Effect of ventricular massage on myocardial LPL activity. Manual massage of the fibrillating ventricles was applied to dogs 6 and 7 . This resulted in depletion of LPL in both ventricles, in contrast to the normal activity determined in the intact atrial muscle (Table IV). The mechanical action of massage upon the right ventricle was sufficient to deplete the muscle of LPL to the same extent as did infarction alone. Massage applied without preceding fibrillation $(\operatorname{dog} 5)$ also resulted in a similar depletion of LPL of the ventricles.

Effect of electrical defibrillation on myocardial LPL activity. Application of electrical defibrillating impulses through the heart produced a marked decrease of the LPL activity of the entire myocardium (Table IV). Electrical stimulation of the myocardium was sufficient to deplete the undamaged atrial muscle of LPL, equal in degree to the depletion produced by infarction, or ventricular massage, or both.

Effect of survival on myocardial LPL after defibrillation by massage and electrical stimulation. The attempts at defibrillation returned the disturbed ventricular contraction to normal sinus rhythm in dogs 13 and 14 ; they were sacrificed after 12 and 48 hours, respectively. Their hearts

TABLE V

Effect of survival on myocardial LPL level after ventricular defibrillation by massage and electrical defibrillation

\begin{tabular}{|c|c|c|c|c|c|c|c|}
\hline \multirow[b]{3}{*}{$\begin{array}{l}\text { Dog } \\
\text { no. }\end{array}$} & \multirow[b]{3}{*}{$\begin{array}{c}\text { Time of } \\
\text { sacrifice* }\end{array}$} & \multicolumn{6}{|c|}{ LPL activity } \\
\hline & & \multicolumn{3}{|c|}{ Heparin-released } & \multicolumn{3}{|c|}{ Acetone-dried powder } \\
\hline & & Atria & $\begin{array}{l}\text { Right } \\
\text { vent. }\end{array}$ & $\begin{array}{l}\text { Infarc. } \\
\text { area }\end{array}$ & Atria & $\begin{array}{c}\text { Right } \\
\text { vent. }\end{array}$ & $\begin{array}{l}\text { Infarc. } \\
\text { area }\end{array}$ \\
\hline & hrs & \multicolumn{3}{|c|}{$F F A, \mu E q / g$ wet wt tissue $/ h r$} & \multicolumn{3}{|c|}{$F F A, \mu E q / g$ protein $/ h r$} \\
\hline $\begin{array}{l}13 \\
14\end{array}$ & $\begin{array}{l}12 \\
48\end{array}$ & $\begin{array}{l}15.3 \\
16.8\end{array}$ & $\begin{array}{l}5.9 \\
6.8\end{array}$ & $\begin{array}{l}1.6 \\
2.5\end{array}$ & $\begin{array}{l}365.5 \\
426.5\end{array}$ & $\begin{array}{r}92.5 \\
119.5\end{array}$ & $\begin{array}{l}62.2 \\
73.6\end{array}$ \\
\hline
\end{tabular}

* Approximate time after placement of the ligature. 
showed a marked depletion of LPL in the area of infarction, less depletion of the uninfarcted but massaged right ventricle, and normal levels in the atrial muscle (Table V). During the time of survival the undamaged atrial muscle was able to recover the lipase, in contrast to the uninfarcted right ventricular muscle, which was apparently damaged by the massage.

\section{DISCUSSION}

Infarction, massage, or defibrillation invariably caused a marked, localized, or diffuse decrease of myocardial LPL activity. A reduction of enzymatic activity might be the result of either inactivation or destruction of LPL, or release of the enzyme into the fluid perfusing the heart. Determination of the circulating LPL activity of blood simultaneously withdrawn from the carotid artery and jugular vein or right auricle, showed a prompt elevation of the arterial LPL activity after coronary arterial ligation, massage, or, particularly, after electrical defibrillation. ${ }^{4}$ Although the possibility that myocardial LPL was destroyed or inactivated cannot be ruled out completely, these results strongly suggest that release of the enzyme from the myocardium may account for the observed depletion of LPL.

It is also possible that infarction, massage, or defibrillation produced irreversible cellular fixation of LPL. If this is the case, the enzyme would not be released by heparin upon incubation in vitro. However, this explanation for the low post-heparin activity is excluded, since the results with myocardial acetone-dried powder showed a parallel depletion of LPL in tissue.

The prompt release of myocardial LPL in amounts resulting in a marked depletion of enzyme by infarction, massage, or defibrillation leads to interesting conclusions regarding the cellular location of the enzyme and the factors causing its liberation. Depletion of LPL in the infarcted muscle occurred as quickly as 3 minutes after coronary ligation. The mechanism of release of myocardial LPL cannot be related to an overt disruption of the cellular integrity, since no significant necrotic changes can develop during this short interval. The LPL depletion that was produced by massage or electrical stimulation is also

${ }^{4}$ Kessler, J. I., and Senderoff, E. Unpublished results. independent of necrotic changes in tissue. Thus, the possible mechanism of release of myocardial LPL would be essentially different from the one causing elevation of peripheral myocardial transaminase, which is attributed to necrotic changes leading to liberation of the intracellular enzyme. Myocardial ischemia, lasting for 45 minutes, was without effect on plasma transaminase level (16, 17 ), whereas LPL, as our results indicate, is released promptly after the coronary ligation.

Ligation resulted in immediate ECG changes, which are assumed to be due to alteration of the surface electrostatic forces over the infarcted area. Manual massage, by producing some degree of subepicardial damage which is known to affect the ECG tracing, can also change the electrostatic forces. While the evidence for disturbed surface electrostatic equilibrium after coronary ligation or massage is indirect, electrical stimulation would undoubtedly affect the electrical charge of the entire myocardium. In this respect the mechanism of LPL release resembles that of heparin and other polyanions $(6-10)$, which are assumed to release the enzyme from its binding sites on the cell surfaces by changing the electrostatic forces that hold it (4).

It is therefore reasonable to suggest that the enzyme has a location on the cell surface, which would also explain its prompt release not related to necrotic changes. This assumption, however, is greatly hampered by two additional factors that should also be considered. The profound metabolic changes caused by the infarction and the related circulatory impairment can affect the cellular permeability. This by itself can result in release of intracellular enzyme, which would not be related to myocardial necrosis or alteration of the electrostatic forces. Furthermore, it has been shown that electrical and chemical stimulation can cause disruption of mast cells with discharge of their heparin content (18) into the circulation. Thus, one can assume that the effect of coronary ligation, massage, and, particularly, electrical defibrillation is secondary to release of myocardial LPL by endogenous heparin, rather than to direct effect on the surface electrostatic forces.

Determination of plasma heparin levels and histochemical examination of the mast cells are required for further elucidation of the mechanism responsible for liberation of myocardial LPL. 


\section{SUM MARY}

High levels of lipoprotein lipase (LPL) activity were determined in the myocardium of dogs. The enzyme was released from heart slices by heparin upon incubation in vitro. The identity of myocardial lipase with LPL was demonstrated by inhibitory studies and calcium phosphate gel adsorption. High levels of LPL activity were also found in myocardial acetone-dried powder.

Myocardial infarction induced by ligation of the coronary artery resulted in a prompt and marked depletion of LPL in the infarcted area. Survival for 24 to 48 hours was without effect on the LPL level of the infarcted muscle.

Manual massage of the ventricles resulted in depletion of LPL of the uninfarcted right ventricle in addition to that of the infarcted muscle. Electrical stimulation depleted the entire myocardium of LPL. Survival of the dog affected the enzyme level of the uninfarcted muscle only; the atria recovered the enzyme completely, whereas the right ventricle, apparently damaged by the effect of massage, recovered LPL only partially.

The marked depletion of LPL was assumed to be due to release of myocardial enzyme into the fluid perfusing the heart. The prompt liberation of LPL was independent of tissue necrosis. This was considered as additional evidence for the prevailing opinion that the enzyme is located on the cell surfaces.

The possible role of infarction, massage, and defibrillation in affecting the surface electrostatic forces in a manner similar to that induced by heparin and other polyanions, is discussed.

\section{ACNOWLEDGMENTS}

Acknowledgments are due to Dr. L. E. Schaefer, Chief, Nutrition Laboratory, for his interest in this work and to Dr. E. D. Korn, National Heart Institute, Bethesda, $\mathrm{Md}$., for his very helpful suggestions and revision of the manuscript. The technical assistance of Miss Celia Perez is appreciated.

\section{REFERENCES}

1. Korn, E. D. Clearing factor, a heparin-activated lipoprotein lipase. I. Isolation and characterization of the enzyme from normal rat heart. J. biol. Chem. 1955, 215, 1.
2. Korn, E. D., and Quigley, T. W., Jr. Studies on lipoprotein lipase of rat heart and adipose tissue. Biochim. biophys. Acta 1955, 18, 143.

3. Korn, E. D. Clearing factor, a heparin-activated lipoprotein lipase. II. Substrate specificity and activation of coconut oil. J. biol. Chem. 1955, $215,15$.

4. Cherkes, A., and Gordon, R. S., Jr. The liberation of lipoprotein lipase by heparin from adipose tissue incubated in vitro. J. Lip. Res. 1959, 1, 97.

5. Gates, H. S., Jr., and Gordon, R. S., Jr. Demonstration of lipoprotein lipase in fasting human serum. Fed. Proc. 1958, 17, 437.

6. Robinson, D. S., and Harris, P. M. The production of lipolytic activity in the circulation of the hind limb in response to heparin. Quart. J. exp. Physiol. 1959, 44, 80.

7. Robinson, D. S., Harris, P. M., and Ricketts, C. R. The production of lipolytic activity in rat plasma after the intravenous injection of dextrane sulphate. Biochem. J. 1959, 71, 286.

8. Bragdon, J. H., and Havel, R. J. The heparin-like activity of certain inorganic anions. Science 1954, $120,113$.

9. Robinson, D. S. The heparin clearing reaction. Pharm. Weekbl. 1957, 92, 949.

10. Havel, R. J., and Bragdon, J. H. Heparin-like activity of polymetaphosphate (abstract). Circulation 1954, 10, 591.

11. Dole, V. P. A relation between non-esterified fatty acids in plasma and the metabolism of glucose. J. clin. Invest. 1956, 35, 150.

12. Trout, D. L., Estes, E. H., Jr., and Friedberg, S. J. Titration of free fatty acids of plasma: A study of current methods and a new modification. J. Lip. Res. 1960, 1, 199.

13. Gordon, R. S., Jr. Unesterified fatty acid in human blood plasma. II. The transport function of unesterified fatty acid. J. clin. Invest. 1957, 36, 810.

14. Lowry, O. H., Rosebrough, N. J., Farr, A. L., and Randall, R. J. Protein measurement with Folin phenol reagent. J. biol. Chem. 1951, 193, 265.

15. Nikkilä, E. A. Partial purification of clearing factor of postheparin human plasma. Biochim. biophys. Acta 1958, 27, 612.

16. Nydick, I., Wroblewski, F., and LaDue, J. S. Evidence for increased serum glutamic oxalacetic transaminase (SGO-T) activity following graded myocardial infarcts in dogs. Circulation 12, 161. 1955

17. Merrill, J. M., Stone, J. L., Grace, J. T., and Meneely, G. R. Decreased activity of glutamic oxalacetic transaminase in infarcted myocardial tissues of the dog. Clin. Res. Proc. 1955, 3, 113.

18. Riley, J. F. The mast cells. Edinburgh, Livingstone, 1959, p. 116. 